CONTRIBUTIONS TOWARD A MONOGRAPH OF THE NOCTUIDAE OF TEMPERATE NORTH AMERICA. REVISION OF HOMOHADENA, GROTE.

\author{
BY \\ John B. Sмiтh, \\ Professor of Entomology, Rutgers College, New Jersey.
}

Genus Homohadena Grt.

[1873. Bull. Buff. Soc. N. H., I, 1890.]

Medium-sized species with the habitus of Hadena, but with rather distinctive maculation. Head moderate or small; front smooth; tongue strong; palpi stout, attaining middle of front. Eyes naked, with variably distinct lashes-this character becoming evanescent here. Antennæ simple, scarcely ciliate even in the male. Thoracic vestiture mixed scales and hair. Collar with crest marked but scarcely prominent. A very small, indefinite, basal thoracic tuft, vestiture else smooth. Abdomen untufted. Legs with rather long, loose hair; tibiæ unarmed, not spinose. Primaries rather elongate-trigonate, apices and outer margin slightly rounded. Ovipositor of female somewhat exserted.

The male genitalia are of the same type as in Oncocnemis, and this genus is its close ally, differing chiefly in the lack of the claw to foretibia.

The species are fuscous gray or brown, with the median lines sometimes wanting, and when present, distinct, black, and single, often connected by a longitudinal black streak or by an inward tooth from the t. p. line.

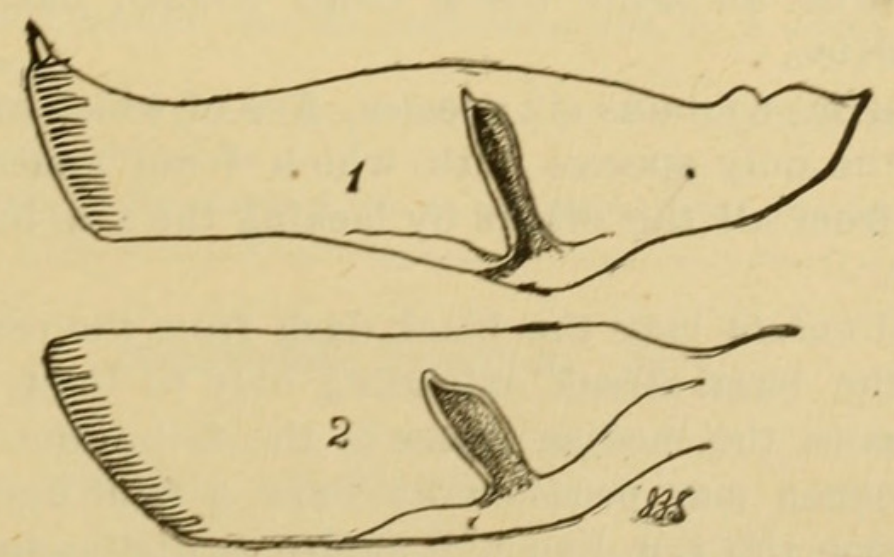

Fig. 1.-Genitalia of $H$. badistriga; 2, of $H$. induta.

The genus is very compact and the species scarcely form distinct groups, though readily separable into series on characters of macula- 
tion. Some of the species are unknown to me, but all are readily placeable even into a synoptic table, from the descriptions, as the maculation is so simple.

There are three series: In the first, the median lines are wanting or punctiform; in the second, the median lines are present, but there is no basal longitudinal line; in the third, the median lines and basal dashes are all present. In all the species the ordinary spots are faint, or more usually entirely wanting.

In the first series are three species-two of them unknown to me, and they seem closely related. So far as can be made out the differences are as follows :

Incomitata has the median lines faintly indicated by venular dots; the veins are more or less evidently black marked, and there is a row of distinct terminal lunules. The color is dark fuscous or red brown. It is from Texas and not uncommon.

In picina, as far as I can gather from the description, the veins are not black marked and there are no terminal lunules. It is from California.

Inconstans is fuscous gray, the collar paler, the lines all lost, the veins darker in the female only. It is from Arizona.

The second series also contains three species, two of them unknown to me.

Figurata lacks the s. t. line, and the median lines are connected by an inward tooth from the t. p. line. The species is recorded from Nevada and California, and must be close to retroversa, in which the basal line is faint, and the s.t. marked by a pale shade only. An obscure specimen of retroversa might readily serve as the type of figurata.

Chorda is a simply marked species, the basal and median lines only distinct, the latter not in anyway connected. The s. t. line is vague, barely traceable; in color it is fuscous gray, the t. p. line nearly straight below the costal angulation. The head is white, with a black line between the antennæ.

Epipaschia is clayey gray, much shaded with black, the t. p. line widely bent, with an acute costal tooth toward base of wing. It is from New Mexico.

The third series contains six species, five of which are known to me.

Vulnerea, the only species with which I am unacquainted, differs prominently from all the others by lacking the t. a. line-a rather unusual feature.

Deserta and induta lack the black dash from the reniform outward. Deserta has the basal streak extending only to the t. a. line, while in induta it crosses the median space to the t. p. line. In the latter species a specimen may occasionally show a faint line over reniform, but in that case the t. a. line will suffice to distinguish it from badistriga with which it might else be confounded. Induta has the line outwardly oblique and distinctly sinuate, while in badistriga the line is evenly outcurved. 
Retroversa and kappa have the ordinary spots, somewhat pale-ringed and usually rather distinct. The former is distinguished by having the t. p. line inwardly toothed at middle, the tooth extending to the t. a. line, but not beyond; basal dash very faint. The latter has the basal dash rather more distinct, becoming prominent before the $t$. a. line and $e^{x t e n d i n g}$ through median space to t. p. line, the connection thus not formed by the tooth of the $t$. p. line. Of retroversa I know only the type.

Badistriga, the type of the genus, is as a rule paler, more grayish. The basal dash is very distinct and prominent, and the outer black streak starts from the orbicular and extends through the reniform to near the outer margin.

\section{SYNOPSIS OF SPECIES.}

Transverse lines wanting, or indicated by venular dots only.

Brownish fuscous, median lines faintly indicated.

Veins black marked; a row of terminal black lunules.............. incomitata.

Veins not black marked; no terminal lunules..................... PICINA.

Fuscous gray, collar paler; lines all lost; veins marked in the $q$ only.inconstans. Transverse lines distinct, the t. p. at least.

Basal longitudinal streak wanting.

S. t. line wanting.

Median lines connected by an inward tooth from t. p. line ........... Figurata.

S. t. line distinct or at least traceable; median lines not connected.

Fuscous gray; t. p. line nearly straight, not as much inflected as usual.cHORDA.

Clayey gray, much shaded with black; t. p. line widely bent, with an acute costal tooth toward base of wing .................... EPIPASCHIA.

Basal longitudinal streak present.

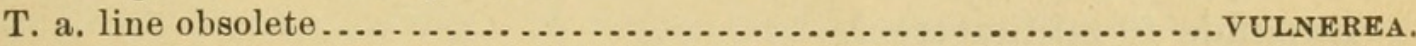

T. a. line distinctly present.

No line from reniform outwardly, crossing t. p. line.

Basal dash extending only to t. a. line........................ DESERTA.

Basal dash extending through median space to t. p. line........... Induta.

A black line crossing reniform, and extending outwardly across t. p. line and t. space.

T. p. line with a strong inward tooth connecting with t. a. line. RETROVERSA.

T. p. line not toothed; median lines connected by a continuation of basal streak.

Basal streak faint; the line crossing t. p. over reniform obscure, shaded; secondaries fuscous :........................................

Basal streak very distinct, as is the streak over reniform; secondaries pale .BADISTRIGA.

\section{Homohadena incomitata Harv.}

1875, Harv. Buff. Bull., III, 6, Homohadena.

1875, Harv. Can. Ent., viI, 136, Homohadena.

Deep dark, somewhat fucous brown, somewhat variable in intensity. Head and collar a richer, more reddish brown. The ordinary lines of primaries are obsolete. Median lines sometimes entirely wanting, usually traceable as a series of black venular dots. S. t. line entirely 
wanting. A row of small terminal lunules; veins more or less evidently black marked. Ordinary spots wanting. Secondaries smoky outwardly, paler basally, with a variably distinct discal dot. Beneath primaries dark smoky fuscous, paler toward inner margin. Secondaries whitish powdery, most evidently so along costal and apical region. A row of outer venular dots; a discal lnnule.

Expands 1.25 to 1.36 inches $=31$ to 34 millimetres.

HaBitaT.-Texas.

An easily recognized species, distinguished by its lack of markings. It varies very little, principally in depth of ground color and in the presence or absence of the venular points. The species is common; yet unfortunately, of the numerous specimens in the accessible collections there was but a single male in which I could fully examine the genitalia. The harpes, however, are very like those of badistriga, except that they lack the heavy corneous spine at upper angle of tip.

Homohadena picina Grt.

1880, Grt. Can. Ent., XII, 257, Homohadena.

"Thorax and primaries unicolorous, dusky fuscous; the median lines indicated by venular dots, incomplete; the posterior line not as flexed as usual; fringes concolorous. Hind wings whitish at base, washed with fuscous exteriorly, the veins soiled; faint traces of a mesial line. Beneath the secondaries are paler, with a distinct dotted line. Eyes naked; body untufted; tibiæ unarmed. A stout, obscurely colored and simply marked form."

Expands 40 millimetres.

Habitat.-California; Mr. Hy. Edwards, No. 7174.

This must be a rather close relation to that form of fortis which was named vorax by Dr. Behrens, though Mr. Grote would scarcely have called the eyes naked, and he says positively "tibiæ unarmed."

\section{Homohadena inconstans Grt.}

1883 Grt. Can. Ent., xv, 28, Homohadena.

"Male and female. An obscure fuscous gray species with naked, lashed eyes; third palpal joint small, female ovipositor visible. Size and appearance of induta, but with the look of an Agrotis belonging to the silens or lagena group. Transverse lines all lost; stigmata wanting. In the female the veins are marked with black, the median vein most decidedly so. In the male there are no marks. The head is smoky and the collar paler. Hind wings fuscous, paler at base, and paler in the male; the veins soiled. Beneath pale and without mark. ings; there is a faint indication of a common line which appears dotted on hind wings of female."

HaвiтAT.-Arizona (Neumœgen).

Unknown to me in nature. 
Homohadena figurata Harvey.

1875, Harv. Can. Ent., vir, 117, Homohadena.

"The body vestiture is scaly, mixed slightly with hairs. The size is that of induta. The color is more grayish than usual, and the basal streak is wanting in the specimen. The uniformly dark griseous primaries have the median lines alone visible; these are narrow, black, approximate, of the usual gothic shape, fused by a black dash below median vein. A series of terminal narrow black streaks. Fringes long, silky gray. Hind wings almost uniformly fuscous with whitish fringes, beneath paler with traces of a transverse line and a discal dot. Fore wings fuscous, with an outer line. Thorax and head like fore wings in color."

Expands 30 millimetres.

Навітат.-Nevada; Mr. Hy. Edwards, No. 2745.

Unknown to me in nature.

\section{Homohadena chorda Grt.}

1880, Grt. Can. Ent, XII, 256, Homohadena.

General color of thorax and primaries a warm brownish gray or fuscous. Head white, with a black line between the antennæ. T. a. line broad black, outwardly oblique, slightly irregular. T. p. line narrower, single, black, not much outcurved over cell, thence in wardly oblique, a little irregular. A broad, diffuse pale gray shade crosses the wing uver the t. p. line, darkening outwardly very gradually to the fuscous terminal space. S. t. line sometimes barely traceable, sometimes preceded by a diffuse black shading. A vague median shade marked by a costal spot and scarcely definable below this. Ordinary spots obsolete, or the reniform only vague, small and pale. Secondaries whitish with soiled veins and a smoky outer border. Beneath gray, powdery, darkening outwardly, a common extra discal line.

Expands 1.25 inches $=31$ millimetres.

Hавітат.-Colorado; Sierra Nevada, California.

A single male from Mr. Edwards's collection is before me. It differs from the Colorado specimen described by Mr. Grote, by the greater obsolescence of the markings; the reniform, median shade, and s. t. line being almost entirely obsolete, while in the description they seem to be fairly evident, if not distinct. The white head with the broad black interantennal line is distinctive and renders the species easily recognizable. The genitalia of the male resemble those of induta most nearly, the clasper being apparently a little shorter, broader, and the tip a little more drawn out. The harpes differ very little.

\section{Homohadena epipaschia Grt.}

1882, Grt. Proc. Kans. A. Sci., viII, 49, Homohadena.

"This singular species has the look of one of the Epipaschice. Fore wings clayey-gray, much shaded with black; lines black, single; t. a.

Proc. N. M. $90-26$ 
somewhat curved and thick; t. p. line widely bent, with an acute costal tooth towards base of wing; s. t. line denticulate, pale, followed by prominent interspaceal black marks, the black terminal space itself cut by pale reins; fringe dark. Hind wings blackish fuscous; beneath, two bands on primaries and terminal black marks more faintly repeated; hind wings gray, with the band bent subterminally; a discal point. Above, a black cloud on center of disc, apparently separating the pale black, clouded, undefined stigmata."

Expanse 30 millimetres.

HАВітAт,-Kansas.

Homohadena vulnerea Grt.

1883, Grt. Can. Ent., xv, 29, Homohadena.

"Eyes naked, lashed; tibiæ unarmed; fore wings light brown; t. a. line obsolete; t. p. line black, single, well removed outwardly; three black median costal dots; a black dash at base below median vein; stigmata very small, inconspicuous, pale; a black dash on cell on each side of the orbicular; veins finely black at extremity, else tending to be pale; fringes checkered; thorax like fore wings; hind wings pure white; beneath with only a common dotted exterior line."

HABITAT.-Arizona. (Neumœgen.)

"This species is simply marked. The eyes are plainly lashed, but in the type of the genus $H$. badistriga, after renewed examination, I am not certain that they are, though I incline to regard them lashed."

Homohadena deserta, sp. nov.

Ground color of thorax and primaries a grayish fuscous; head darker, deep brown, palpi paler; primaries with pale-gray suffusion along the costal region and accompanying the t. p. line; basal line distinct; $t$. a. line broad, black, evenly oblique; a narrow black longitudinal streak from base to the t. a. line; t. p. line black, narrow, single, widely outeurved over the cell, deeply incurved below; s. t. line irregular, marked by an interrupted series of paler marks in the interspaces; a series of interspaceal black lines; veins darker, marked throughout; ordinary spots evident; orbicular oval, elongate, pale ringed, else concolorous ; reniform small, irregular, incompletely pale ringed; a series of black terminal lunules, and a pale line at base of fringes; a vague, diffuse, scarcely traceable median shade; secondaries white, with soiled veins and outer margin; beneath white, powdery along costal and outer margin; primaries with an incomplete outer line and discal spot; secondaries with a punctiform outer line, the points venular.

Expands 1. 25 inches $=31$ millimetres.

HABiтAT.-Colorado desert.

A single male specimen from Mr. Edwards's collection. It is easily distinguishable from all its allies by the lack of connecting streak between the median lines, and the lack of a black streak from the reniform outward. 
In genital structure it resembles badistriga, differing in the broader harpes, lacking the stout spine at upper angle of tip, and in the stiil more slender clasper, the tip yet more drawn out.

\section{Homohadena induta Harv.}

1874, Harv. Buff. Bull., II, 274, Homohadena.

1875, Harv. Can. Ent., vir, 118, Homohadena.

1875, Morr. Can. Ent., viI, $91=$ retroversa.

1875, Harv. Buff. Bull., III, 6, an. $8 p$. dist.

Head, thorax, and primaries varying from fuscous gray to a dull red brown, the fuscaus gray form the most common. Primaries with the ordinary lines all present. T. a. line somewhat oblique outwardly, bisinuate. T. p. line widely bent over the cell, then with a deep inward curve narrowing the median space by fully one-half. A longitudinal black streak from base through median space to the t. p. line. Ordinary spots very faint or wanting-when present, a trifle discolorous; the reniform with an indefinite paler edging. Median shade faint, very slightly darker, sometimes wanting. S. t. line pale, powdery, strongly dentate, marked by a darker preceding shade. This feature is also very variable, the line sometimes being entirely obsolete, no trace of the preceding shade being visible, while all intermediate forms are to be found. Secondaries dirty white with an indefinite outer dark border and an outer line. Also a faint discal lunule. Rarely the entire secondaries are fuscous or smoky; beneath powdery, varying from reddish to smoky fuscous, with a darker outer line not quite crossing the wing.

Expands 1.12 to 1.25 inches $=28$ to 31 millimetres.

\section{HАвітат.-Texas.}

The species is rather a variable one in some fẹatures. The ground color, the median shade, the distinctness of the s. t. line-all are variable. The constant features are the course of the transverse lines and of the basal dash, and these give the species a characteristic appearance that sticks to it through all its variations. The harpes are rather broad, nearly parallel, and only slightly oblique at tip, where they are spinulose inwardly. The clasper arises from inferior margin of harpe, rather behind the middle, aud is somewhat dilated toward tip, the outer angle of which is drawn out.

The species is common.

\section{Homohadena retroversa Morr.}

1874; Morr. Proc. Bost. Soc. N. H., xviI, 157, Homohadena. 1875, Harv. Buff. Bull., III, $6=k a p p a$.

Head, thorax, and primaries fuscous gray. Primaries with basal line marked on costa only. T. a. line very distinct, with a slight and rather even outward curve. T. p. line strongly exserted over cell, then with a long inward tooth to the t. a. line, thence forming a regular outward curve to the hind margin. The basal line is faint and narrow, as is also 
the line extending through reniform and outwardly to s. t. line. S. t. line faintly marked by a slightly darker shade and the somewhat more gray terminal space. The ordinary spots are outlined by rather broad and somewhat indefinite pale rings, else concolorous. A row of small terminal lunules. Secondaries smoky, toward base paler; a smoky median line. Beneath powdery, primaries smoky, with an indefinite discal dot and a trace of an outer line on costa. Secondáries much paler, discal lunule distinct; a distinct extra discal dark line beyond which the outer margin is darker.

Expands 1.28 inches $=32$ millimetres.

Habitat.--Missouri.

Of this species I have seen the type from Mr. Tepper's collection and a specimen in Dr. Riley's possession. It is very close to kappa, of which Mr. Grote eites it a synonym, following Dr. Harvey's suggestion to that effect in Buff. Bull., III, 6. In addition to the differences enumerated in the general introduction, this species lacks the venular dark streaks which mark the s.t. line in kappa. Figurata Harvey musteome very close to this.

\section{Homohadena kappa Grt.}

Head, thorax, and primaries varying from fuscous gray to brown. Primaries with darker shading, especially marked in the s. t. space. Basal line marked on costa only. T. a. line with a variably marked but always slight outward curve. T. p. line with a wide outward bend over discal cell, strongly incurved below, and sinuate to the hind margin. The line is followed by a distinct, though narrow pale line. S. t. line marked by a darker preceding shade, through which there is a series of interspaceal black dashes. The basal line is faint nearly to the t. a. line, then very distinct and broad to the t. p. line. The superior longitudinal dash begins between the ordinary spots, crosses the reniform and extends to the s. t. line, usually broadening out and transformed into a blackish shade. The ordinary spots are moderate, concolorous, rather indefinitely pale ringed. A series of black terminal lunules. Secondaries smoky fuscous, paler at base and with a faint median line, obscured in dark specimens. Beneath primaries dark, powdery, with traces of a discal spot and outer line. Secondaries paler, more powdery; discal spot and line distinct.

Expands 1.35 to 1.40 inches $=34$ to 35 millimetres.

Навітат.-Missouri, Iowa, Kansas, Texas.

Somewhat variable in ground color and consequent distinctness of maculation, but as a whole a very recognizable species. The differences between it and retroversa have been already pointed out. From badistriga it differs evidently by the very faint basal dash, which in the former is a prominent feature. The species is not rare, but in the museum series there is not, unfortunately, a single male with the abdomen intact, so that I can not describe the genitalia. 
Homohadena badistriga Grt.

1872, Grt. Trans. Am. Ent. Soc., Iv, 20, Hadena.

1873, Grt. Buff. Bull., I, 181, Homohadena.

1875, Grt. Check List Noct, pl. I, f. 5, Homohadena.

1878, Lint. Ent. Contr., Iv, 93, Homohadena.

Head, thorax, and primaries varying from ashen gray to fuscous brown, collar always paler, head with a more reddish tint. T. a. line with a slight and variable outward curve. T. p. line strongly outcurved over cell, incurved but scarcely sinuate below. The basal dash is very distinct to t. a. line, somewhat narrowing beyond and rarely not attaining the t. p. line. The superior line extends usually from the t. a. line across both ordinary spots to the s. t. line, and often to the outer margin. The ordinary spots are usually somewhat darker, indefinite, rarely obsolete, sometimes with paler rings. S. t. line very variably distinct; usually it is entirely wanting, rarely it is quite definite, irregular and pale. A series of interspaceal black dashes through outer portion of s. t. space usually extending to the outer margin. Quite frequently the terminal space is somewhat darker, and the veins are white marked. In many specimens the veins are pale marked throughout, and sometimes the entire costal region is paler. A series of small terminal lunules. Secondaries varying from an almost immaculate dirty white to smoky, with base paler, often with a distinct extra discal line and discal spot. Beneath powdery, very variable in shade, with a more or less distinct discal spot and outer line.

Expands 1.12 to 1.30 inches, 28 to 33 millimetres.

Hавітат.-Maine to Texas; west to Kansas.

A decidedly variable species yet easily distinguished by the very distinct broad, black basal dash and the longer dash through the outer portion of wing. The paler collar is also a distinctive feature. The species is rather common.

The genitalia of the male are distinctive, the harpes narrow somewhat at the middle, slightly widening to the scarcely oblique tip, which is at the inner edge fringed with spinules, and has a stout, short spine at the upper angle. The clasper is long, rather slender, very slightly dilated toward tip, the outer angle acutely drawn out. The larva feeds on honeysuckle.

Homohadena elda French, does not belong to this genus, but belongs rather to a section of Hadena proper as that genus is at present constituted. The genus is represented in the National Museum collection by a fair series of species, but all the forms described by Mr. Grote from the Newmogen collection are wanting. 


\section{$2 \mathrm{BHL}$ Biodiversity Heritage Library}

Smith, John Bernhard. 1891. "Contributions toward a monograph of the Noctuidae of temperate North America.Revision of Homohadena, Grote." Proceedings of the United States National Museum 13(838), 397-405. https://doi.org/10.5479/si.00963801.13-838.397.

View This Item Online: https://www.biodiversitylibrary.org/item/53445

DOI: https://doi.org/10.5479/si.00963801.13-838.397

Permalink: https://www.biodiversitylibrary.org/partpdf/52065

\section{Holding Institution}

Smithsonian Libraries

\section{Sponsored by}

Smithsonian

\section{Copyright \& Reuse}

Copyright Status: Public domain. The BHL considers that this work is no longer under copyright protection.

This document was created from content at the Biodiversity Heritage Library, the world's largest open access digital library for biodiversity literature and archives. Visit BHL at https://www.biodiversitylibrary.org. 